\title{
ПОШИРЕНІСТЬ ВЕНЕРИЧНИХ ЗАХВОРЮВАНЬ І ФАКТОРИ, ЩО СПРИЧИНЯЮТЬ ЇХ РОЗВИТОК
}

\author{
М. Я. Марищук
}

Екстрена медична допомога, м. Луцьк

\begin{abstract}
У статті проаналізовано поширеність венеричних захворювань по Волинській області, а також фактори, що спричиняють виникнення даних захворювань.
\end{abstract}

\section{PREVALENCE OF VENEREAL DISEASES AND FACTORS THAT CONTRIBUTE TO ITS DURLOPMENT}

\author{
M. Ya. Maryshchuk \\ Emergency care, Lutsk, Volyn region
}

The article analyzes the prevalence of venereal diseases in Volyn region, as well as factors that contribute to the occurrence of these diseases.

Вступ. Венеричні хвороби - одна із серйозних соціальних і психологічних проблем сьогодення. Рівень захворюваності на сифіліс за останні 10 років зріс у десятки разів. Значного поширення набули захворювання, що передаються статевим шляхом другого покоління: хламідіоз, мікоплазмоз, трихомоніаз, цитомегаловірусна інфекція [6].

Соціальне значення венеричних захворювань визначається їх розповсюдженістю, тяжкістю наслідків для здоров'я хворого, впливом на нащадків. Негативна демографічна ситуація значною мірою зумовлена високим рівнем захворювань, що передаються статевим шляхом. Вкрай недостатньою є поінформованість молоді, підлітків про тяжкі захворювання та їх небезпечність [3].

Основна частина. Сифіліс - це хронічне інфекційне захворювання, що викликається блідою трепонемою, уражає всі органи і тканини організму, здатне до тривалого та рецидивуючого перебігу. Шляхи зараження: статевий, побутовий (предмети, якими користувався хворий - склянки, ложки, зубні щітки, бритви), трансфузійний, трансплацентарний (від хворої сифілісом матері плодові) [1].

Статистично найбільше хворих виявляють при васерманізації соматичних хворих, вагітних, як статеві контакти, найменший показник самостійних звернень

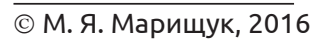

[4]. Станом на 01.01.2015 р. на диспансерному обліку по Волинській області зареєстровано 839 осіб.

Основна причина поширеності венеричних хвороб - це випадкові статеві зв'язки, що зумовлені як соціальними причинами, так і причинами моральноетичного характеру. Велику роль у зараженні й розповсюдженості венеричних хвороб має алкоголізм і наркоманія. Велика міграція населення, війни, акселерація молоді, невиявлення джерел і статевих контактів - це також ті чинники, що спричиняють зростання ЗПСШ [2].

Венеричні хвороби другого покоління (хламідіоз, мікоплазмоз, трихомоніаз), а також гонорейна інфекція стають причинами захворювань сечостатевої системи, органів дихання, суглобів, нервової та серцевосудинної систем, призводять до безпліддя і імпотенції та інших тяжких ускладнень [5].

Як бачимо із таблиці 1, в динаміці спостерігається тенденція до збільшення сифілітичної інфекції по Волинській області за 2013-2015 роки. Чоловіків хворіє більше, ніж жінок, хворих підлітків на дану патологію в 2013 році не було, а за наступні два роки було виявлено 2 випадки.

Хворих дітей на сифіліс у 2013-2014 році не було зареєстровано, а в 2015 виявлено 2 хворих (1 хлопчик + 1 дівчинка). За останні 10 років не зареєстровано жодного випадку вродженого сифілісу. 
Таблиця 1. Поширеність сифілісу на території Волинської області за 2013-2015 роки на 100 тисяч населення

\begin{tabular}{|lccc|}
\hline \multicolumn{1}{c}{ Роки } & 2013 & 2014 & 9 міс. \\
Захворюваність серед дорослого & 116 & 145 & 107 \\
населення & $11,2 \%$ & $14,0 \%$ & $10,3 \%$ \\
Чоловіки & 56 & 65 & 52 \\
Жінки & $48,3 \%$ & $44,8 \%$ & $48,6 \%$ \\
Діти & 60 & 80 & 55 \\
& $51,7 \%$ & $55,2 \%$ & $51,4 \%$ \\
Підлітки & - & - & $2(1$ хл. +1 дів.) \\
& - & 1 (дів.) & 1 (дів.) \\
\hline
\end{tabular}

Такий показник - це результат якісної і тісної співпраці акушерів-гінекологів, венерологів та урологів. До інших захворювань, що передаються статевим шляхом відносять: гонорею, хламідіоз, мікоплазмоз, трихомоніаз.

Аналізуючи статистичні дані таблиці 2, можна зробити висновок, що в 2014 році відбулося зниження захворюваності на гонорею на 25,4 \%, а за 9 місяців 2015 року зниження на 7,5%. За 3 роки зареєстрована тільки 1 дитина (дівчинка) і двоє підлітків (1 дівчинка і
1 хлопчик). Позитивним $\epsilon$ те, що в 2015 році на гонорейну інфекцію дітей та підлітків не зареєстровано.

Як видно із даних таблиці 3, в динаміці спостерігається зниження поширеності трихомонадної інфекції серед дорослого населення. Насторожує високий показник захворюваності на трихомоніаз серед дитячого населення. Найбільш активно дану патологію виявляють акушери-гінекологи 68,5 \%, дерматологи $26,1 \%$, урологи - 5,4\%.

таблиця 2. Поширеність гонореї на території Волинської області за 2013-2015 роки на 100 тисяч населення

\begin{tabular}{|lccc|}
\hline \multicolumn{1}{c}{ Роки } & 2013 & 2014 & 9 міс. \\
Захворюваність серед дорослого & 127 & 94 & 64 \\
населення & $12,2 \%$ & $9,1 \%$ & $6,2 \%$ \\
Чоловіки & 88 & 76 & 51 \\
Жінки & $69,3 \%$ & $9,1 \%$ & $79,7 \%$ \\
Діти & 39 & 18 & $13 \%, 3 \%$ \\
Підлітки & $30,7 \%$ & 1 дів.) & - \\
& - & $0,1 \%$ & - \\
\hline
\end{tabular}

Таблиця 3. Поширеність трихомоніазу на території Волинської області за 2013-2015 роки на 100 тисяч населення

\begin{tabular}{|lccc|}
\hline \multicolumn{1}{c}{ Роки } & 2013 & 2014 & 9 міс. \\
Захворюваність серед дорослого & 1156 & 1084 & 761 \\
населення & $111,5 \%$ & $104,4 \%$ & $73,2 \%$ \\
Чоловіки & 193 & 157 & 123 \\
& $16,7 \%$ & $14,5 \%$ & $16,2 \%$ \\
Жінки & 963 & $85,5 \%$ & 638 \\
Діти & $83,3 \%$ & - & $83,8 \%$ \\
Підлітки & - & $15 \%$ & 4 \\
& 8 & $0,8 \%$ & $0,4 \%$ \\
\hline
\end{tabular}


таблиця 4. Поширеність хламідіозу на території Волинської області за 2013-2015 роки на 100 тисяч населення

\begin{tabular}{|lccc|}
\hline \multicolumn{1}{c}{ Роки } & 2013 & 2014 & 9 міс. \\
Захворюваність серед дорослого & 829 & 705 & 2015 \\
населення & $79,9 \%$ & $67,9 \%$ & $26,5 \%$ \\
Чоловіки & 164 & 169 & 47 \\
Жінки & $19,8 \%$ & $24,0 \%$ & $17,0 \%$ \\
Підлітки & 665 & 536 & 229 \\
& $80,2 \%$ & $36,0 \%$ & - \\
\hline
\end{tabular}

Статистичні дані таблиці 4 підтверджують тенденцію до зниження поширеності хламідійної патології. Хворих дітей не зареєстровано, є випадки захворювання серед підлітків у 2013-2014 роках.

Висновок. Венеричні хвороби продовжують залишатися серйозною проблемою для людського здоров'я і для країни в цілому. Для боротьби з даною

\section{ЛІТЕРАТУРА}

1. Новосад Л. С. Шкірні та венеричні хвороби / Л. С. Новосад, В. В. Лабінський. - К. : Здоров'я, 2000. С. 111-137.

2. Бернацький П. Й. Організація правового забезпечення боротьби з венеричними хворобами / П. Й. Бернацький, О. І. Хара, О. А. Кащенко. - Тернопіль, 1996. - 19 c.

3. Контактные инфекции, передающиеся половым путем / под. ред. И. И. Маврова, М. Н. Бухарович, Б. Т. Глухенький. - К. : Здоров'я, 1989. - 384 с. патологією потрібно об'єднати громадську профілактику, загально-державні, лікувально-просвітні заходи та особисту профілактику, яка полягає у високій моральності, застосуванні засобів контрацепції та своєчасного звернення до спеціалізованих медичних закладів противенеричної допомоги.

4. Потоцький І. І. Шкірні та венеричні хвороби : підручник для медучилищ / І. І. Потоцький. - К. : Вища школа, 1981. - 200 c.

5. Самцов В. И. Руководство по кожным и венерическим болезням / В. И. Самцов. - Л. : Медицина, 1990. - 240 с.

6. Скрипкин Ю. К. Кожные и венерические болезни : учебник для студентов медицинских институтов / Ю. К. Скрипкин. - М. : Медицина, 1980. - 552 с. 